\title{
УДК 81'282'373:070
}

DOI https://doi.org/10.32447/2663-340X-2019-6-21

\section{ДІАЛЕКТНА ПОБУТОВА ЛЕКСИКА У ЗАСОБАХ МАСОВОЇ КОМУНІКАЦІЇ}

\author{
Левченко Тетяна Миколаївна \\ кандидат педагогічних наук, \\ дочент кафедри украйнської лінгвістики та методики навчання \\ ДВНЗ «Переяслав-Хмельниџький державний педагогічний університет \\ імені Григорія Сковороди» \\ вул. Сухомлинського, 32, Переяслав, Украӥна
}

\begin{abstract}
У статті порушено одну з важливих лінгвістичних проблем-використання діалектизмів у мові засобів масової комунікації. Дослідження діалектної лексики тісно пов'язане із стилістикою масмедіа, яка вивчає мовні засоби, в тому числі діалектизми, у складі мови публіцистичного дискурсу. 3 'ясовано функціонально-стилістичні можливості діалектної побутової лексики у засобах масової комунікації. Зазначено, щзо найчастіше у публіцистичних текстах натрапляємо на побутову діалектну лексику - назви місиевих реалій і понять, щуо не відомі і не використовуються поза межами певного говору чи групи споріднених говорів. 3 циієї причини побутова діалектна лексика зазвичай не має відповідників у літературній мові, а означувані нею реалї і поняття або передаються описово, або позначаються тими самими словами, щуо й у говорах. Відзначено, що діалектизми стають не тільки маркерами індивідуального стилю автора, а ще й відбувається популяризаџія мовленнєвого наміру за допомогою нестандартної лексики, автор публікації робить акцент на неповторності предмета та естетичній правильності його назви, він визнає, що цей діалектизм лаконічно, фактографічно, краще за будь-які описи справляється з номінативною функцією. Найчастіше діалектна лексема пояснюється у самому тексті, автор публікаціі намагається ввести незнайоме слово у коло лінгвоестетичних иінностей. Засоби масової комунікацї як потужний публічний фактор сприяють не тільки популяризаџії діалектної лексики, яка є складовою субстандарту, а й закріпленню ї̈ в украӥнській літературній мові. Так, друковані ЗМІ, завдяки включенню в текст діалектної лексики і фразеології, сприяють конкретизації значень, розвитку в окремих слів нових значень, розииренню. лексичної сполучуваності, поглибленню стилістичної диференціації слів $і$ виразів. Діалектні одинииі охоплюють переважно сфери життя, пов'язані з побутом, родинними стосунками, виробничою діяльністю носїв місиевого говору. Сучасна преса є не тільки джерелом лексичних і стилістичних інновацій, а й базою формування, розвитку мови сучасного субстандарту.
\end{abstract}

Ключові слова: мова засобів масової комунікації, діалектизми, субстандарт, побутова лексика, публіичстичний дискурс.

Постановка проблеми в загальному вигляді та обтрунтування ії актуальності. Функціонування діалектної лексики у різних сферах масової комунікації приваблює увагу як сучасних лексикологів, діалектологів, так і лінгвістів, які досліджують мову засобів масової комунікації. Лексична система є частиною мови, що найдинамічніше розвивається, оскільки в ній відображається життя суспільства, його історія, побут, культура, усі ті процеси, які супроводять формування нації як частину суспільства. Відповідно до цього спостерігаємо багатоплановість у вивченні словникового складу мови і слова як лінгвістичної одиниці, здатної відображати особливості української мови.

Нині спостерігаємо інтенсивний вплив зовнішніх і внутрішніх чинників на літературну мову, що веде до змін на усіх їі рівнях. Їх дія на сучасну літературну мову настільки виходить за межі усталених мовних процесів, що не може не привертати увагу лінгвістів.

Дослідження діалектної лексики тісно пов'язане із стилістикою засобів масової комунікації, яка вивчає мовні засоби, в тому числі тери- торіальні діалектизми, у складі мови публіцистичного дискурсу. Факт діалектної диференціації мови був усвідомлений ще античною стилістикою і граматикою, де була створена низка термінів на позначення неусвідомленого чи ненавмисного використання діалектизмів у літературній мові. До початку XIX століття функціонування діалектизмів розглядалося як відхилення від мовних норм, тобто відхилення і помилки, яких потрібно уникати. Філософські погляди початку XIX ст. утвердили самостійність і самоцінність усної регіональної лексики як народних слів і словосполучень.

Аналіз останніх досліджень і публікацій. Поняття діалектизмів як стилістичної категорії та основи формування літературної норми в сучасній українській мові розглядали С. Я. Єрмоленко, П. Ю. Гриценко. Функції діалектизмів у загальнотеоретичному аспекті досліджували С. Я. Єрмоленко, Д. В. Бондаренко, С. Г. Тичина та інші. Проблеми взаємодії української літературної мови і територіальних діалектів вивчали М. А. Жовтобрюх, І. Г. Матвіяс. Високим ступенем стилістич- 
ної виразності та експресивним потенціалом відзначаються діалектизми, які на сьогодні є досить продуктивними елементами мови засобів масової комунікації. Функціонально-семантичні вияви призначення діалектизмів у мові української періодики досліджували у своїх працях М. В. Бігусяк, I. Кириченко, О. Пискач, В. Путрашик та ін.

Однак, незважаючи на певну кількість праць, присвячених вивченню мови 3МI, в українській лінгвістиці бракує досліджень мови субстандартної лексики у засобах масової комунікації, зокрема таких, де б досліджувалося функціонування територіальних діалектизмів.

Мета і завдання статті. Метою статті $\epsilon$ 3'ясування функціонально-стилістичних можливостей територіальної діалектної лексики у мові засобів масової комунікації.

Відповідно до мети статті визначено завдання дослідження: 3'ясувати чинники, які сприяють входженню та вживанню діалектної лексики у мові сучасної публіцистики; виявити основні тематичні групи діалектних одиниць; виявити i проаналізувати стилістичні особливості діалектної лексики у засобах масової комунікації.

Виклад основного матеріалу дослідження. Діалектну побутову лексику репрезентують різні тематичні групи. Зокрема, діалектні лексеми у засобах масової комунікації не тільки номінують одяг і взуття, страви і напої, предмети побуту вони описують епоху, створюють певний емоційний фон, а подекуди передають соціальний та індивідуальний образ героїв публікацій.

Тематична група назви одягу та взуття репрезентована такими лексемами: сардак, сердак - рід верхнього теплого короткого сукняного одягу [9, IX, с. 58]: «Гуиули і гуцулки на його світлинах позують у вишитих сорочках, у традиційних кептарях і сердаках, молодиці-у мистецьки вив 'язаних хустках, старі жінки - у перемітках, голови старших чоловіків покриті волохатими клепанями, молодших - рогатими джумирями або багато прикрашеними крисанями» («Галінфо, 23.05.18»); «Hi, я таки піду і перевдягнусь. Президента треба зустрічати урочисто. Одягну вишивану сорочку і сердак», - каже старенька жінка, щзо теж приїхала ровером, щзоб побачити президента» («Укрінформ», 02.08.19); лейбик чоловічий або жіночий верхній одяг (звичайно без рукавів)_[9, IV, с. 471]: «Утім цүікаво, коли пошиттям сердаків (нагадує пальто з візерунками та вишивками, аплікаціями $і$ китицями у народному стилі) та лайбиків (той же сердак, але без рукавів) займається чоловік» («Укрінформ», 13.10.18); довганя - «Майже у кожному комплекті - довга вишита сорочка - «довганя» («Ужгородські новини», 08.11.18); крисаня - капелюх, бриль [9, IV, с. 348]: «А Валерій Сиротюк подарував Папі Римському гуиульське вбрання: крисаню $і$ кепmap» («Zaxidnet», 22.05.18); кеnтар - у гуцулів верхній хутряний одяг без рукавів [9, IV, с. 141]: «A також гуцульська безрукавка «кептар» (бунда), довгий фартух «плат», верхній одяг «сердак» («Ужгородські новини», 08.11.18); ногавиці суконні штани [9, V, с.439]: «Не знаю куди подів свої ногавиці» («Новини Поділля», 13.09.16); гуня - верхня одежа $з$ домотканого грубого, переважно нефарбованого сукна. [9, II, с. 194]: «Найкращзюю вважається гуня з довгим ворсом. Коротковорсні називають зневажливо - «обскубаними» («Zik.ua» 12.01.16); «Ще якихось півстоліття тому чи не кожен житель Річки у цюю пору одягав теплу та водонепроникну гуню» («Закарпаття», 02.11.18); «Крім ліжників, майстриня відтворює інше стародавнє ремесло гучулів - виготовляє своєрідні ткані иуби - гуні» («Правда», 22.01.18); кошуля - сорочка [9, IV, с.318]: «Приміром, коли Наталія Бучинська співала «Зелене жито», на сцені підтанцьовували якісь тітоньки середнього віку в кошулях (чи льолях) - одне слово, ие такі довгі сорочки, щзо використовують в народному костюмі як спіднє» («Детектор медіа», 26.18.15); гачі-итани [9, II, с.42]: «Чоловічий одяг включав білу сорочку власного виробу, вишиту спереду, пущена по итанях - «портіницях», з чорного або фарбованого на червоно сукна - зимою білих вовняних «гачах», підперезаних широким ременем «чересом» - $i$ з різними прикрасами-витисками й «дармовисами» («Ужгородські новини», 12.08.18).

До діалектизмів, що вживаються у сучасній пресі 3 метою точного відтворення історичних подій, належать і слова, що передають зміст понять i реалій, які характеризують ближчі до сучасності історичні періоди. Діалектизми тут виступають у функції стилістично-нейтральної лексики, за допомогою якої правдиво і точно відтворюються історичні події, називають реалії, що характеризують більш чи менш віддалену від сучасності історичну епоху. Назви побутових $i$ господарських предметів представлені такими лексемами: рурка - труба малого діаметру [9, VIII, с. 471]: «Панянки, які не хотіли палити волосся гарячою руркою, використовували перевірені часом папільйотки» («Правда», 22.09.19); ліжник кустарний килим, коц [9, IV, с.509]: «Наявність ліжників у хаті була ознакою доброго майнового стану родини, і чим більше було ліжнників, тим багатшою вважалася наречена» («Високий Замок», 22.02.19); кои - ворсовий пристрижений однобічний килим [9, IV, с. 314]: «Майстриня охоче розповідає про технологію створення коца з овечої вовни» («Високий Замок», 22.02.19); верета - різнокольоровий килим з грубої вовни [9, I, с. 329]: «У скрині, на якій два металеві хрести-обереги, зберігається грубе домоткане полотно, розииті хрестиком (чорне з червоним) обруси, якими накривали столи, застеляли пічлежанку, верета для ослінчиків, а також святковий одяг, щуо його носили українці на початку минулого століття «Високий Замок», 13.06.13); mайстра - гуцульська торбина, яку носять через плече [9, X, с. 17]: «Селенин винайшов нову тай- 
стру (торбу)» («Карпатські Новини», 15.02.17); табівка - гуцульська шкіряна торбина 3 орнаментом, яку носять на ремені через плече [9, X, с. 9]: «У залі «Газда» широко експоновані традиційний чоловічий гуиульський одяг, сумки-табівки, топіриі, келефи, різноманітні порохівнииі» («RISU», 16.12.16); бартка - маленька сокира [9, I, с. 108]: «Серед иих гуиульських атрибутів особливе місие займає бартка» («Укрінформ», 13.03.19);

Деякі діалектні лексеми ми не знаходимо в словниках, можливо вони функціонують в обмеженій сфері, але швидше за все справа в темпоральній обмеженості їх використання. Свого часу вони не були зафіксовані, а згодом втратили сферу свого застосування. Тому, ці діалектизми пояснюються в самому тексті, а значить автор орієнтується на широкий загал читачів і намагається ввести незвичні лексеми в коло лінгвоестетичних цінностей. Таке явище спостерігаємо в низці публікацій: «I шимату до посуду моя бабуся називала «митка», а дошку до прання - «миглівниця»» («Високий Замок», 17.12.16); «A от ще назви предметів побуту: «рихіль»-засув до дверей, «кливець» - молоток, «подря» - горище, «nрічі» - ліжко, «чіфка»-дровітня» («Високий Замок», 17.12.16); «Стіл на Святвечір обов'язково стелять білим обрусом, а вже на Різдвяний сніданок ми маємо інший, вишиваний» («Zaxid. net», 22.05.18). «Два ліжка, нічна шафка, стіл $i$ фотель» («Старий Замок «Паланок», 17.01.16).

Одна 3 найважливіших складових матеріальної культури українського народу - це страви, напої, продукти харчування, тому тематична група назви страв та напоїв широко репрезентована у засобах масової комунікації. Для неї характерна не тільки стійкість і наявність значного шару лексики, але й зміна в часі аж до повного зникнення, що вимагає уважного фіксування ії складових. У сучасній пресі натрапляємо на такі діалектичні одиниці: пляцок - картопляник; 2) млинець 3 тіста, замішаного на вареній картоплі $[8$, с. 432]: «Сiдаєщ за столик на березі тихого страву, споглядаєш, як полює на жаб і дрібну рибу чапля та наминаєш смачнючі пляцки з тертої бульби» («Гал-інфо», 05.08.19); флячки - свинячі або телячі тельбухи, порізані на шматочки і зварені в пшоняній каші [9, Х, с. 610]: «До речі, тут спробував дивовижні флячки!» («Гал-інфо», 05.08.19); бриндза - сир 3 овечого молока [9, I, с. 236]: «Традииійно, тут можна придбати найрізноманітнішу продукиію від гуиульських сироварів: бринзу, будз та вурду» («Укрінформ», 23.07.18); квасеиь - щавель [9, IV, с. 131]: «Новиною ивогоріч стала поява «Пекельної кухні», на якій варили кашу, куліш та борщ з квасцем» («Семенівські вісті», 22.09.19); паленка - горілка [9, VI, с. 24]: «Коли вже став дорослим і почав експериментувати з різновидами паленки самостійно, зрозумів, що на українському ринку досить мало якісного алкогольного продукту» («Високий Замок», 15.03.19); книдлі - «Гості залюбки смакують книдлями, заправленими сиром $і$ шкварками, буряковим салатом зі сиром - неймовірне поєднання смаків, а також салатом із листя буряка - гички» («Високий Замок», 27.06.19); обарінок - бублик [9, V, с. 463]: «У моєму рідному Дрогобичі иі бублики колись називали обарінками, з наголосом на другому складі. Продавали їх щороку на Спаса старенькі бабиі під иерквою, коли у нас відзначали храмове свято» («Високий Замок», 12.06.18); вертута - «Як зазначили організатори, на заходi спробують створити найдовщу в Украӥні вертуту, повідомляє» («Укрінформ», 12.09.19).

Діалектизми набувають стилетворчого статусу, вони формують ядро матеріалу, який побудований на межі розмовного і публіцистичного стилю. Автори публікацій демонструють, як діалектна лексика, що репрезентує тематичну групу назви посуду створює естетично правильний образ реальності, реконструює та перейменовує предметний світ. Діалектна лексема гальба - півлітровий кухоль [9, II, с. 22]: «Кажуть, полюбляв перехилити гальбу пива тут і Володимир Ленін зі своєю бойовою соратнищею і дружиною» («Старий Замок «Паланок», 14.05.18); філіжанка - чашка [9, X, с. 592]: «Згодом тут заснували «Клюб шанувальників кави», де шановне товариство за філіжсанками кави вело бесіди на шляхетні теми» («Галицькі контракти», 02.11.14); «Спробуйте запитати ужгородия: що значить для нього звичайна філіжсанка кави?» («Старий Замок «Паланок», 27.09.19); пательня - сковорода [9, VI, с. 92]: «Цибулю для юшки варто припекти на сухій пательні або над газом - буде иікавіший смак» («Zaxid.net», 22.05.18); бербениия діжечка, барило [9, I, с. 157]: «Раніме ї̈ витримували до року - гуцули закладали бриндзю y дерев'яні гелетки чи бербениці, споживали протягом року до наступного сезону, вона через пару місяиів набувае специфічної гостроти» («Укрінформ», 20.10.18); «Тримають сир у дерев 'яних бербеницях або скляних банках дуже довго - до двох років» («Сьогодні», 13.09.19); «А розпочався фестиваль із відкриття бербениці зі свіжою бриндзею, якою частували всіх охочих» («Ужгород», 09.09.19); «У музеї Бойчуків широко представлені речі полонинського побуту» («БукІнфо», 31.10.16); коновка - те саме, що відро [9, IV, с. 261]: «Це - коновки, в яких роблять сир; бербенички, в які набивають бринзу; барфела, де зберігають сир; масляничка, в якій збивають зі сметани масло» («БукІнфо», 31.10. 16); путера - дерев'яна посудина для виготовлення овечого сиру [9, VIII, с. 403]: «Так, щойно здоєне молочко старший переливає y путеру (смерекову діжку) і ставить ї̈ на півтори години біля вогнища, аби воно охолонуло» («Сьогодні», 13.09.19); «У домашніх умовах вариво прочіджують через марлю, а на полонинах - через ялинові гілочки - у великі дерев'яні путері (казани)» («Закарпаття», 28.07.17). 
Висновки та перспективи подальших досліджень. Діалектна лексика номінує сегменти позамовної дійсності, які в літературній мові не мають відповідників. 3 їх допомогою автор публікації описує місцеві реалії життя, вводить у публіцистичний текст лексичні діалектні слова або словосполучення, що відображають особливості матеріальної і духовної культури народу певної території.

Діалектичні одиниці слугують засобом індивідуалізації героя публіцистичного тексту. Мовна індивідуальність героя публікацій здійснюється завдяки наділенню його мовлення індивідуальними рисами, якими він відрізняється. Вкраплення в мовлення певних діалектних одиниць ідентифікує героя як представника певної етнічної групи, забезпечує переконливості та етнографічної достовірності. У сучасних засобах масової комунікації спостерігаємо намагання віддзеркалити мовленнєву органіку носія діалекту, зробити позалітературний елемент яскравою одиницею власного стилю, продемонструвати повне занурення у мовленнєве середовище свого героя.

Діалектизми збагачують літературну мову, адже вони $є$ джерелом постійного поповнення лексичного складу літературної мови лексемами, функціонування яких територіально обмежене. Подекуди діалектна лексика виконує експресивну функцію, якщо іiї цілеспрямовано використовують у мові засобів масової комунікації. Використання діалектичних одиниць було і залишається особливістю сучасної української літературної мови в тих жанрах, які пов'язані з описом реалій сільського життя. Це означає, що в сучасній ситуації діалекти не тільки реагують на вплив літературної мови,але й самі впливають на неї.

\section{ЛIТЕРАТУРА}

1. Бігусяк М.В. Стилістичні функції діалектизмів у мові місцевої преси. Наукові праиі Кам'янещь-Подільського національного університету імені Івана Огієнка. Філологічні науки. 2013. Вип. 34. С. 35-39.

2. Бондаренко Д.В. Стилістична функція лексичних діалектизмів в українській художній літературі. Структура і розвиток українських говорів на сучасному етапі. XV Респ. діалектолог. нарада : тези доп. і повідомл. : до IX Міжнар. з'їзу славістів / Ін-т мовознав. ім. О. О. Потебні АН УРСР ; відп. ред. М. В. Никончук. Житомир : [б. в.], 1983. С. 180-181.

3. Гриценко П.Ю. Діалектизм. Українська мова : енциклопедія / редкол. : Русанівський В. М., Тараненко О. О., Зяблюк М. П. та ін. 2-ге вид., випр. і допов. К. : Вид-во «Українська енциклопедія» ім. М. П. Бажана, 2004. C. $146-147$.

4. Срмоленко С.Я. Сучасна літературна мова і діалекти. Рідне слово. 1972. Вип. 6. С. 6-17.

5. Жовтобрюх М. Проблеми взаємодії української літературної мови і територіальних діалектів. Мовознавство. 1973. № 1. С. 3-15.

6. Пискач О. Використання діалектної лексики в публіцистичному тексті (на матеріалі закарпатської районної преси). Сучасні проблеми мовознавства та літературознавства. Зб.наук.праць. Вип. 6. Збірник пам’яті Кирила Галаса. Ужгород. 2002. С. 281-287.

7. Путрашик B.I. Функціонально-стилістичні можливості діалектизмів у заголовках сучасної закарпатської газети (на матеріалі часопису «Старий Замок «Паланок»). Ученые записки Таврического нащионального университета им. В. И. Вернадского. Серия : Филология. Социальные коммуникации. 2011. Т.24 (63). № 4, ч. 1. C. $169-176$.

8. Словник буковинських говірок / За заг.ред. Н.В. Гуйванюк. Чернівці. Рута. 2005. 688 с.

9. Словник української мови в 11 т. К.: Наук. думка, 1970-1980. Т. 1-11.

\section{REFERENCES}

1. Bigusyak M.V. (2013). Stylistychni funktsii dialektyzmiv u movi mistsevoi presy [Stylistic functions of dialectisms in the language of domestic press]. Naukovi pratsi Kamianets-Podilskoho natsionalnoho universytetu imeni Ivana Ohiienka. Filolohichni nauky, 34, 35-39 [in Ukrainian].

2. Bondarenko D.V. (1983). Stylistychna funktsiia leksychnykh dialektyzmiv v ukrainskii khudozhnii literaturi [Stylistic function of lexical dialectisms in Ukrainian literature]. Struktura i rozvytok ukrainskykh hovoriv na suchasnomu etapi. XV Resp. dialektoloh. narada : tezy dop. i povidoml : do IX Mizhnar. zizdu slavistiv / In-t movoznav. im. O.O. Potebni AN URSR; vidp. red. M. V. Nykonchuk. Zhytomyr : [b. v.], 180-181 [in Ukrainian].

3. Hrytcenko P.Yu. (2004). Dialektyzm. Ukrainska mova : entsyklopediia [Dialectism. Ukrainian language : encyclopedia] / redkol. : Rusanivskyi V. M., Taranenko O. O., Ziabliuk M. P. ta in. 2-he vyd., vypr. i dopov. Kyiv : Vyd-vo «Ukrainska entsyklopediia» im. M. P. Bazhana, 146-147 [in Ukrainian].

4. Yermolenko S.Ya. (1972). Suchasna literaturna mova i dialekty [Modern literature language and dialects]. Ridne slovo, 6, 6-17 [in Ukrainian].

5. Zhovtobriukh M. (1973). Problemy vzaiemodii ukrainskoi literaturnoi movy i terytorialnykh dialektiv [Problems of interaction of Ukrainian literary language and territory dialectisms]. Movoznavstvo, 1, 3-15 [in Ukrainian].

6. Pyskach O. (2002). Vykorystannia dialektnoi leksyky v publitsystychnomu teksti (na materiali zakarpatskoi raionnoi presy) [Using of dialect vocabulary in journalistic text (on the material of Transcarpathian regional press)]. Suchasni problemy movoznavstva ta literaturoznavstva, 6, 281-287 [in Ukrainian]. 
7. Putrashyk V.I. (2011). Funktsionalno-stylistychni mozhlyvosti dialektyzmiv u zaholovkakh suchasnoi zakarpatskoi hazety (na materiali chasopysu «Staryi Zamok «Palanok») [Functional and stylistic possibilities of dialetctisms in headings of modern Transcarpathian newspaper (on the material of «Staryi Zamok «Palanok»)]. Uchenye zapiski Tavricheskoho natsyonalnoho universiteta im. V. I. Vernadskoho, 24 (63), 169-176 [in Ukrainian].

8. Slovnyk bukovynskykh hovirok [Dictionary of Bukovynian subdialects]. Chernivtci: Ryta [in Ukrainian].

9. Slovnyk ukrainskoi movy: v 11 tt. [The Ukrainian language dictionary]. Kyiv: Nauk. Dumka [in Ukrainian].

\title{
DIALECT EVERYDAY LEXIS IN MASS MEDIA
}

\author{
Levchenko Tetiana Mykolaivna \\ Candidate of Pedagogical Sciences, \\ Associate Professor of Ukrainian Linguistic \\ and Methodology of Studying Department \\ SHEE «Pereiaslav-Khmelnytskyi Hryhoriy Skovoroda \\ State Pedagogical University» \\ 32, Sukhomlynskyi Str., Pereiaslav, Ukraine
}

The article deals with one of the important linguistic problems - the use of dialecticisms in the language of mass communication. The study of dialect vocabulary is closely related to the stylistics of the mass media, which studies linguistic means, including dialecticisms, as part of the language of journalistic discourse. Functional and stylistic possibilities of dialect vocabulary in mass media are found out. It is noted that most often in publicist texts we come across household dialect vocabulary - names of local realities and concepts that are not known and are not used outside of a certain speech or group of related speeches. For this reason, household dialect vocabulary usually has no equivalent in literary language, and its realities and concepts are either conveyed descriptively or are indicated by the same words as in speech. It is noted that dialectisms become not only markers of the individual style of the author, but also there is a popularization of speech intent with the help of non-standard vocabulary, the author of the publication emphasizes the uniqueness of the subject and the aesthetic correctness of its name, he acknowledges that this dialecticism is concise, in fact, better than any descriptions handle the nominative function. Most often the dialect lexeme is explained in the text itself, the author of the publication tries to introduce a unknown word into the circle of linguo-esthetic values. Mass communication as a powerful public factor contributes not only to the popularization of dialect vocabulary, which is a constituent of the sub-standard, but also to its consolidation in the Ukrainian literary language. Thus, the printed media, through the inclusion in the text of dialect vocabulary and phraseology, contribute to the specification of meanings, the development of new meanings in new words, expansion. lexical connectivity, deepening of stylistic differentiation of words and expressions. Dialectic units cover mainly the spheres associated with life, family relations, the production activity of native speakers. The modern press is not only the source of lexical and stylistic innovations, but also the basis for the formation, development of the language of the modern substandart.

Key words: mass media, dialectisms, substandart, household vocabulary, journalistic discourse. 